\title{
Nonclinical Study Title
}

National Cancer Institute

\section{Source}

National Cancer Institute. Nonclinical Study Title. NCI Thesaurus. Code C95108.

The brief identifier that summarizes the design and purpose of a biomedical research investigation on non-human subjects. 